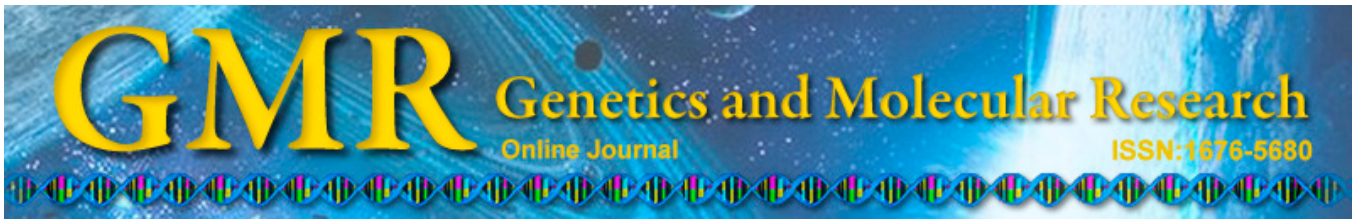

\title{
Analysis of skin color change and related gene expression after crossing of Dongxiang black chicken and ISA layer
}

\author{
X.D. Zhang', H.H. Wang', C.X. Zhang ${ }^{2}$, Q.H. Li ${ }^{1}$, X.H. Chen ${ }^{2}$ and L.F. Lou ${ }^{1}$ \\ ${ }^{1}$ Hangzhou Academy of Agricultural Sciences, Hangzhou, China \\ ${ }^{2}$ Zhejiang Guangda Poultry Breeding Company, Hangzhou, China \\ Corresponding author: X.D. Zhang \\ E-mail: bigzhengliang@hotmail.com \\ Genet. Mol. Res. 14 (3): 11551-11561 (2015) \\ Received January 26, 2015 \\ Accepted May 18, 2015 \\ Published September 28, 2015 \\ DOI http://dx.doi.org/10.4238/2015.September.28.7
}

\begin{abstract}
This study evaluated the effects of the autosomal dominant $F m$ gene in conjunction with the sex-linked $I d$ gene on skin color and related gene expression. Ten Dongxiang black cocks were selected to build ten families by mating 60 individuals of ISA B-line layers. The skin color of the $\mathrm{F}_{1}$ generation was observed at different time points. At 126 days, 36 chickens were slaughtered, and gene expression of TYRP1, $T Y R P 2, M C 1 R$, and $E D N R B$ in breast skin was assessed by quantitative RT-PCR. The ratio of Dongxiang black chickens with white skin chicks in the $F_{1}$ generation to that of non-white was 3:7 (HoFF: HeFf). At 126 days, all $F_{1}$ generation cocks showed white skin (115/115), while the percentages of hens with black skin were $100 \%$ (HoFF, 27/27) and $53.75 \%$ (HeFf, 43/80). The change in skin color peaked between 42 and 84 days. The offspring of HoFF displayed significantly higher expression of $M C 1 R$, compared with those of $\operatorname{HeFf}(\mathrm{P}<0.05)$. The "L" value of hen's skin was significantly lower, and TYRP1 and TYRP2 expression was significantly higher $(\mathrm{P}<0.05)$ than in cocks with the same $F m /$ $\mathrm{fm}$ genotype. These findings indicate the presence of homozygous and heterozygous $\mathrm{Fm}$ in Dongxiang black chickens, with the offspring of
\end{abstract}


homozygous birds showing a higher percentage of black skin percentage. The expression of the four genes studied was correlated with skin color, with TYRP1 and TYRP2 representing the most suitable molecular markers.

Key words: Cross; Dongxiang black chicken; Gene expression; Skin color

\section{INTRODUCTION}

The Dongxiang black chicken is one of 107 Chinese domestic chickens recorded in "Animal Genetic Resources in China: Poultry" (China National Commision of Animal Genetic Resources, 2011). The bird is characterized by its black feathers, and its comb, beak, skin, muscle, bone, tibia, and toe are almost black. It is also known for its blue-shell eggs. Interestingly, its black skin, bone, and muscle are caused by melanin deposition, which is known as dermal hyperpigmentation or fibromelanosis. Many signaling pathways are involved in melanin formation, secretion, migration, and deposition. For example, the Wnt $/ \beta$-catenin, EDNRB and KIT signaling pathways are involved upstream during melanoma development and differentiation (Grichnik et al., 1998; Imokawa et al., 2000; Jin et al., 2001). The genes involved include the transcription factors $P A X 3, S O X 10, M I T F$, the endothelin receptor EDNRB and its ligand $E D N 3$, and the tyrosine kinase receptor KIT and its ligand KITL. The genes involved downstream of melanin synthesis and migration include the melanocortin receptor $M C 1 R$ and its ligand $a-M S H$, and the antagonistic ligand $A S I P$, which belongs to the tyrosinase gene family (Barsh, 1996; Hou and Pavan, 2008). The above-mentioned genes affect the expression of black traits to varying degrees. For example, TYRP1 is involved in the maintenance of tyrosinase stability and in the regulation of its catalytic activity, and therefore affects the proliferation and apoptosis of melanoma (Sarangarajan et al., 2000; Wu, 2003). TYRP2 is a melanocyte-specific enzyme that catalyzes the non-decarboxylative tautomerization of Ldopachrome to 5,6-dihydroxyindole-2-carboxylic acid in the melanin biosynthesis pathway (Pak et al., 2000; Fang et al., 2001). In addition, $M C 1 R$ affects the enzyme activity of members of the tyrosinase family, which determines the color of the animal coat by regulating the synthesis of eumelanin (Shu et al., 2006).

Some studies have shown that the skin color of black chickens results from interaction between the autosomal dominant Fm gene and the sex-linked pigment inhibited Id gene (Hutt, 1949; Stolle, 1968). The Fm gene was shown to be significantly associated with a 10.3 to 13.1 $\mathrm{Mb}$ region on chromosome 20, while the $I d$ gene was mapped to $72.3 \mathrm{Mb}$ at the end of the long arm of chromosome Z, although the specific location remains unclear (Dorshorst et al., 2010, 2011). Interestingly, studies have shown that the $I d$ gene is epistatic to $F m$, and melanin deposition induced by $F m$ was inhibited in the presence of Id. For example, Zhang et al. (2000) studied Taihe Silky crossed with other yellow tibia and white skin chicken breeds, and found that offspring cocks displayed white skin, while hens had black skin at 90 days old. Huang et al. (2003) found that the offspring of Sichuan Mountain black chicken crossed with a yellow tibia and skin chicken breed tended to show light skin. However, these studies did not consider the effect of the purebred skin color genotypes ( $F m$ homozygous or heterozygous), and only analyzed the skin color of hybrid offspring. In addition, in-depth studies on the expression of melanin-related genes in the $F_{1}$ generation with different skin color genotypes are scarce.

During the breeding and production of black chickens, the degree of blackness of the 
skin color and its uniformity among populations are important factors of commercial value. This is because it is generally considered that higher melanin content in black chicken represents increased nutritious value. As we observed in conservation populations of Dongxiang black chicken, the shank are all black (id homozygous) and the skin are mainly black or light black (only 4 to $6 \%$ white). These observations indicate the presence of $F m$ homozygotes and heterozygotes among these populations. The present study used Dongxiang black chicken crossed with ISA B-line layers with white skin ( $f m$ homozygous) and yellow tibia (Id homozygous). The $\mathrm{F}_{1}$ generation was characterized, and the expression of melanin-related genes TYRP1, TYRP2, $M C 1 R$, and $E D N R B$ was assessed. Our results provide new insights to further understand the genetics of Dongxiang chicken. In addition, the data presented here suggest in-depth molecular mechanisms for skin color differences at the transcription level. Overall, our findings provide a scientific basis for further development of black chicken breeding and hybrid utilization.

\section{MATERIAL AND METHODS}

\section{Animals and grouping}

ISA B-line layers were obtained from Guangda poultry breeding company in Zhejiang Province, and animals had been bred for 15 generations. Dongxiang black chickens collected from Dongxiang County in Jiangxi Province had been bred for 12 generations at Guangda poultry breeding company. Ten Dongxiang cocks were selected randomly and coded from one to 10 . They all had black or light black skin. According to the mating ratio of 1:6, Dongxiang cocks were mated with sixty ISA B-line female to generate ten families. Eggs were collected, incubated, and all hatched chicks were marked with wing tags. This study was performed with the approval of the Animal Ethics Committee of Hangzhou Academy of Agricultural Sciences, conforming to the Guide of the Care and Use of Laboratory Animals (The National Academies, USA). All animals were provided voluntarily by Guangda poultry breeding company, and fed at the chicken farm of Hangzhou Academy of Agricultural Sciences. No specific permissions were required for this study.

Based on genetic rules of $F m$ and $I d$ genes, Dongxiang black chicken showed the patterns summarized in Table 1. Parental groups included $\mathrm{HoFF}$ and $\mathrm{HeFf}$, and $\mathrm{F}_{1}$ groups were HoFfIi, HoFfi_, HeffIi, HeFfIi, Heffi_, and HeFfi_. With an $\mathrm{Fm} / \mathrm{Fm}$ homozygous Dongxiang cock, the genotype of the $\mathrm{F}_{1}$ generation should be only $\mathrm{Fm} / \mathrm{fm}$ and there would be no white skin chick. However, if a Dongxiang cock is $\mathrm{Fm} / \mathrm{fm}$ heterozygous, the genotypes of the $\mathrm{F}_{1}$ generation should be $F m / f m$ and $f m / f m$, indicating the presence of white skin chicks.

\begin{tabular}{|c|c|c|c|c|}
\hline \multirow[t]{2}{*}{$\mathrm{P}$ group } & \multirow[t]{2}{*}{ Cross Mode } & \multicolumn{2}{|c|}{ Putative genotypes } & \multirow[t]{2}{*}{$F_{1}$ group } \\
\hline & & $\mathrm{P}$ & $F_{1}$ & \\
\hline HoFF & $\begin{array}{l}\text { Dongxiang } \mathrm{x} \\
\text { ISA B-line }\end{array}$ & $F m / F m ; i d / i d\left({ }^{\circledR}\right)$ & $F m / f m ; I d / i d\left(\delta^{\lambda}\right)$ & HoFfli \\
\hline \multirow{3}{*}{$\mathrm{HeFf}$} & & $f m / f m ; I d / I_{-}(+)$ & $\begin{array}{l}F m / f m ; i d /\left(\begin{array}{l}(p) \\
f m / f m ; I d / i d(1)\end{array}\right.\end{array}$ & $\begin{array}{l}\text { HoFfi } \\
\text { Heffli }^{-}\end{array}$ \\
\hline & $\begin{array}{l}\text { Dongxiang } \mathrm{x} \\
\text { ISA B-line }\end{array}$ & $F m / f m ; i d / i d(ð)$ & $F m / f m ;$ Id/id $\left(d^{\prime}\right)$ & HeFfli \\
\hline & & $f m / f m ; I d / I_{-}(+)$ & 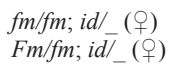 & $\begin{array}{l}\text { Heffi_ } \\
\text { HeFfi_ }\end{array}$ \\
\hline
\end{tabular}

P group: Groups based on different $F m$ genotypes of Dongxiang black chickens. $\mathrm{F}_{1}$ group: Groups based on different $F m$ and $I d$ genotypes of hybrid offspring. 


\section{Feeding management}

All test birds of the $F_{1}$ generation were reared indoors from 1 to 42 days, before outdoor stocking, at five chicken per square meter. Chicken were fed a maize-soybean diet that contained $11.9 \mathrm{MJ} / \mathrm{kg}$ of metabolizable energy and $192 \mathrm{~g} / \mathrm{kg}$ of crude protein from 1 to 42 days, and $12.1 \mathrm{MJ} / \mathrm{kg}$ of metabolizable energy and $158 \mathrm{~g} / \mathrm{kg}$ of crude protein from 42 to 126 days.

\section{Skin color observation and sampling}

The skin color of each chicken was recorded for the breast at 1,2,84, and 126 days, as black, light black and white.

At 126 days, the "L," "a," and "b" values for every chicken were determined by a portable colorimeter (Chin-Spec, China). The "L" value represented the brightness coefficient, which comprised a scale from 0 to 100 , with 0 and 100 indicating black and white, respectively. A positive value for " $a$ " represented red, while a negative value indicated green. A positive value for "b" represented yellow and the negative value represented blue. Six chickens from each $\mathrm{F}_{1}$ group were selected randomly and slaughtered (a total of 36 chickens). Breast skin was clipped quickly from each bird and preserved in liquid nitrogen.

\section{RNA extraction and real-time fluorescence quantitative PCR}

Total RNA was extracted from chicken breast skin using a total RNA extraction kit (Axygen, USA). The quality of RNA was evaluated on 1.5\% agarose gel electrophoresis and using BioSpec-nano spectrophotometer (Shimadzu, Japan). First strand cDNA was synthesized from $2 \mu \mathrm{g}$ total RNA with the M-MLV reverse transcription kit (Promega, USA) and stored at $-20^{\circ} \mathrm{C}$.

Primer characteristics are shown in Table 2. All primers were synthesized by Sangon Biotech Co., Ltd. (Shanghai, China). PCR amplification was carried on a Bio-Rad IQ5 PCR machine. The 12.5- $\mu \mathrm{L}$ PCR included: cDNA, $1.0 \mu \mathrm{L}$; pH 8.0 SDW, $4.75 \mu \mathrm{L}$; SYBR Green I Premix, $6.25 \mu \mathrm{L} ; 10 \mu \mathrm{M}$ Forward primer, $0.25 \mu \mathrm{L} ; 10 \mu \mathrm{M}$ Reverse primer, $0.25 \mu \mathrm{L}$. The PCR was carried out at $95^{\circ} \mathrm{C}$ for $1 \mathrm{~min}, 95^{\circ} \mathrm{C}$ for $15 \mathrm{~s}$, and $63^{\circ} \mathrm{C}$ for $25 \mathrm{~s}$, for a total of 40 cycles; melting curves were generated at 55 to $90^{\circ} \mathrm{C}$.

\begin{tabular}{|c|c|c|c|c|}
\hline Gene & GenBank ID & Chr. & Primer sequence & Product size (bp) \\
\hline \multirow[t]{2}{*}{$18 \mathrm{~S} r R N A$} & AF173612.1 & & F: 5' CCGGACACGGACAGGATTGACA 3' & \\
\hline & & & R: 5' CAGACAAATCGCTCCACCAACTAAG 3' & 94 \\
\hline \multirow{2}{*}{ TYRPI } & NM_205045.1 & Z & F: 5' CCTGGATGGACTGGACCTACCT 3' & \\
\hline & & & R: 5' GTCACCTTGGCTTGGTGAAGAG 3' & 119 \\
\hline \multirow[t]{2}{*}{ TYRP2 } & NM_204935.1 & 1 & F: 5' GCAGCTGCCAACGATCCCATC 3' & \\
\hline & & & R: 5' GGTGAAACCGCTTCATCCACTCA 3' & 82 \\
\hline \multirow{2}{*}{$M C l R$} & NM_001031462.1 & 11 & F: $5^{\prime}$ CCTGCTCTGCCTCATTGGCTTCT $3^{\prime}$ & \\
\hline & & & R: 5' GGTAGATGGTGGGCTGCTTCTG 3' & 131 \\
\hline \multirow[t]{2}{*}{$E D N R B$} & NM_001001127.1 & 1 & F: 5' GATCTGTTGTCCCTGGAGGAAAGA 3' & \\
\hline & & & R: 5' GGAACGGAAGTTATCGTATCCGTGA 3' & 78 \\
\hline
\end{tabular}




\section{Data analysis}

Skin "L", "a", and "b" values, and gene expression levels of TYRP1, TYRP2, MC1R, $E D N R B$ in each group are reported as means $\pm \mathrm{SD}$. For data with normal distribution, single factor ANOVA was used for assessment by the SPSS 21.0 software. Differences between traits were tested using the Duncan method. For data with non-homogeneous variance, the non-parametric test for independent samples was used. In this case, differences between traits were assessed using the Kruskal-Wallis method. A difference was considered to be statistically significant at $\mathrm{P}<0.05$.

\section{RESULTS}

\section{Hatch chick numbers and skin color}

The properties of the Dongxiang-ISA $F_{1}$ generation are shown in Table 3. The Dongxiang cocks coded 1,8 , and 10, had 77 offsprings with no white chicks, indicating that they belonged to the HoFF group. The remaining seven Dongxiang cocks had 184 offspring, which belonged to the HeFf group: 13.6 to $72.2 \%$ white chicks constituted the offspring, with an average percentage of $47.8 \%(88 / 184)$ for each cock.

\begin{tabular}{|c|c|c|c|c|}
\hline Cock code & Hatch chick numbers & Chick numbers (white skin) & White chick percentage & P Group \\
\hline 1 & 27 & 0 & $0 \%$ & HoFF \\
\hline 2 & 22 & 3 & $13.6 \%$ & $\mathrm{HeFf}$ \\
\hline 3 & 26 & 15 & $57.7 \%$ & $\mathrm{HeFf}$ \\
\hline 4 & 18 & 13 & $72.2 \%$ & $\mathrm{HeFf}$ \\
\hline 5 & 21 & 12 & $57.1 \%$ & $\mathrm{HeFf}$ \\
\hline 6 & 30 & 13 & $43.3 \%$ & $\mathrm{HeFf}$ \\
\hline 7 & 34 & 19 & $55.9 \%$ & $\mathrm{HeFf}$ \\
\hline 8 & 26 & 0 & $0 \%$ & HoFF \\
\hline 9 & 33 & 13 & $39.4 \%$ & $\mathrm{HeFf}$ \\
\hline 10 & 24 & 0 & $0 \%$ & HoFF \\
\hline
\end{tabular}

HoFF: Fm genotype of the Dongxiang cocks was $F m / F m$ homozygous. HeFf: $F m$ genotype of the Dongxiang cocks was $\mathrm{Fm} / \mathrm{fm}$ heterozygous.

\section{Skin color changed during the growth process}

The changes observed in skin color at 1, 42, 84, and 126 days are shown in Figure 1. With growth, chickens with black or light black skin became gradually lighter. Interestingly, the skin color of all cocks became totally white $(115 / 115,100 \%)$, while that of hens was mainly light black $(70 / 107,65.42 \%)$ at 126 days. The percentage of skin color change peaked between 42 and 84 days. The percentages of cocks changing from black or light black to white were $87.5 \%$ (HoFF group, 35/40) and 89.2\% (HeFf group, 33/37). The percentages of hens changing from black to light black were $70.4 \%$ (HoFF group, 19/27) and 44.2\% (HeFf group, 19/43). In the HeFf group, 50.7\% (38/75) and 46.3\% (37/80) of cocks and hens, respectively, maintained a white skin color from 1 to 126 days (Figure $1 \mathrm{~A}$ and B). Periodicity photos of $\mathrm{F}_{1}$ generation are displayed in Figure 2, and show chickens with different skin color on hatching day, during growth, and on the slaughtering day. 


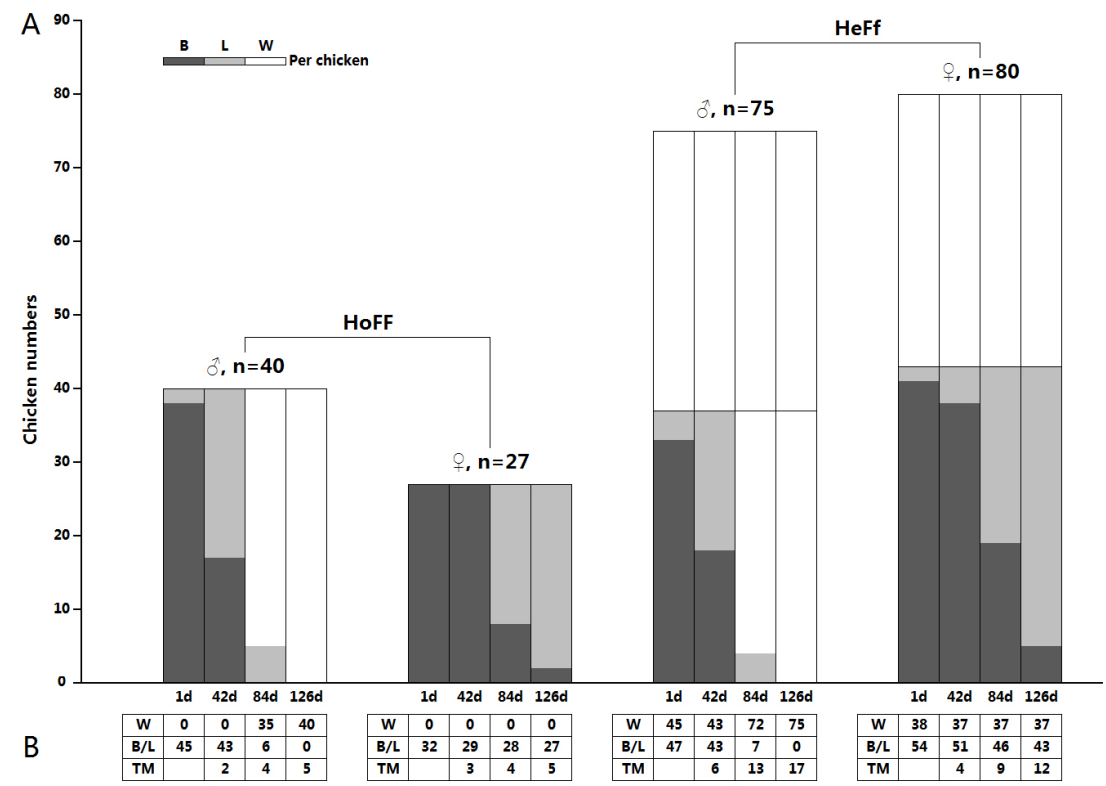

Figure 1. Skin color change in test chickens. A. Summary of the skin color change of chickens in each group. The height of the column chart represents the number of chickens at 126 days. The color of the column chart represents the chicken's skin color at each time point. B: black skin color; L: light black skin color; W: white skin color; HoFF: $F m$ genotype of the Dongxiang cocks was $F m / F m$ homozygous; HeFf: $F m$ genotype of the Dongxiang cocks was $\mathrm{Fm} / \mathrm{fm}$ heterozygous. B. Data represent chicken numbers at each time point. B/L: black or light black skin color; TM: total missing chickens (including dead and wing tag lost).

\section{A}

B

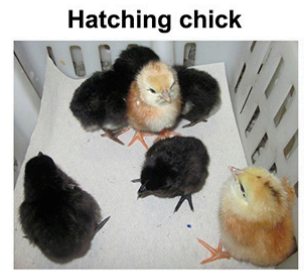

C

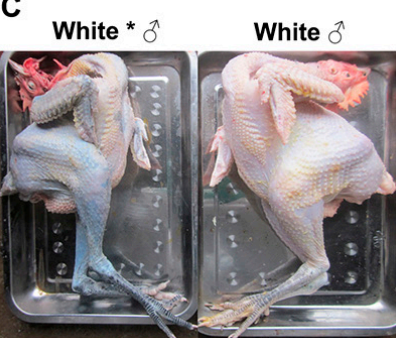

Black

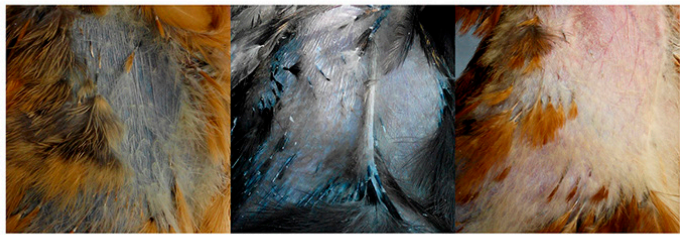

D

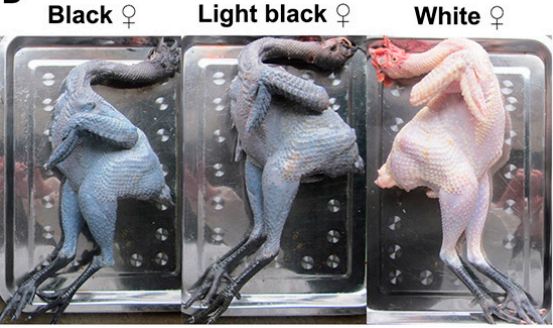

Figure 2. Periodicity images of the $\mathrm{F}_{1}$ generation. A. Hatching chicks with three different skin colors. B. Black, light black, and white skin at the breast side between 42 and 84 days. C. Skin color of slaughtered cocks at 126 days. The cock marked with the star has white skin on the breast side, but the sacral, back, and leg remain light black. D. Skin color of slaughtered hens at 126 days. From left to right, the hens showed black, light black and white skin. 
The skin color and chicken number of each experimental group at 1 and 126 days are summarized in Table 4. The color change in the $\mathrm{F}_{1}$ generation conformed to the test mating prediction. Notably, Dongxiang cocks of the HoFF group were $\mathrm{Fm} / \mathrm{Fm}$ homozygous and the skin color of their offspring was black or light black at day 1 . At 126 days, the skin color of all cocks was white, while hens were black or light black. The ratio of white to black or light black skin was 40:27 (prediction ratio was 1:1, not significant by Chi-squared test). Conversely, Dongxiang cocks of the HeFf group were $\mathrm{Fm} / \mathrm{fm}$ heterozygous. At day 1, white skin chicks were obtained and the ratio of white to black or light black conformed to the prediction, for both cocks and hens. At 126 days, cocks were all white and hens were black, light black, or white. The ratio of hens with white skin to animals with black or light black skin was 112:43 (prediction ratio was 3:1, not significant by Chi-squared test).

Table 4. Skin color and numbers of test chicken at $1 \mathrm{~d}$ and 126 days.

\begin{tabular}{|c|c|c|c|c|c|c|c|c|}
\hline \multirow[t]{2}{*}{$\mathrm{P}$ group } & \multirow[t]{2}{*}{ Sex } & \multicolumn{2}{|c|}{ Skin color } & \multirow[t]{2}{*}{$\mathrm{F}_{1}$ group } & \multicolumn{2}{|c|}{ Numbers } & \multicolumn{2}{|c|}{ Chi-square value $^{1}$} \\
\hline & & 1 day & 126 days & & 1 day & 126 days & 1 day & 126 days \\
\hline \multirow[t]{2}{*}{$\mathrm{HoFF}$} & $\hat{0}$ & $\mathrm{~B} / \mathrm{L}$ & W & HoFfli & 45 & 40 & 2.195 & 2.522 \\
\hline & 우 & $\mathrm{B} / \mathrm{L}$ & $\mathrm{B} / \mathrm{L}$ & HoFfi_ & 32 & 27 & & \\
\hline \multirow[t]{4}{*}{$\mathrm{HeFf}$} & $\hat{\delta}$ & $\mathrm{W}$ & W & Heffli ${ }^{-}$ & 45 & 38 & 0.043 & 0.622 \\
\hline & & $\mathrm{B} / \mathrm{L}$ & W & HeFfIi & 47 & 37 & & \\
\hline & 우 & $\mathrm{W}$ & W & Heffi_ & 38 & 37 & 2.783 & \\
\hline & & $\mathrm{B} / \mathrm{L}$ & $\mathrm{B} / \mathrm{L}$ & HeFfi_- & 54 & 43 & & \\
\hline
\end{tabular}

W: white skin color; B/L: black or light black skin color. HoFF: $F m$ genotype of the Dongxiang cocks was $F m /$ Fm homozygous; HeFf: Fm genotype of the Dongxiang cocks was $F m / f m$ heterozygous. HoFfli: cocks with $F m /$ $\mathrm{fm}$ and Id/id genotype in offspring of Dongxiang $\mathrm{Fm} / \mathrm{Fm}$ homozygous; HoFfi_: hens with $\mathrm{Fm} / \mathrm{fm}$ and $\mathrm{id} /$ _ genotype in offspring of Dongxiang $\mathrm{Fm} / \mathrm{Fm}$ homozygous; Heffli: cocks with $\mathrm{fm} / \mathrm{fm}^{-}$and $\mathrm{Id} / \mathrm{id}$ genotype in offspring of Dongxiang $\mathrm{Fm} / \mathrm{fm}$ heterozygous; HeFfli: cocks with $\mathrm{Fm} / \mathrm{fm}$ and Id/id genotype in offspring of Dongxiang $\mathrm{Fm} / \mathrm{fm}$ heterozygous; Heffi_: hens with $\mathrm{fm} / \mathrm{fm}$ and $i d /$ _ genotype in offspring of Dongxiang $\mathrm{Fm} / \mathrm{fm}$ heterozygous; HeFfi_: hens with $\mathrm{Fm} / \mathrm{fm}$ and $\mathrm{id} /$ _ genotype in offspring of Dongxiang $\mathrm{Fm} / \mathrm{fm}$ heterozygous.

${ }^{1}: \chi_{0.05(\mathrm{df}=1)}^{2}=3.841, \chi_{0.05(\mathrm{df}=3)}^{2}=7.815$.

\section{Skin color distribution of the $F_{1}$ generation at 126 days}

The "L," "a," and "b" color values of the breast skin at 126 days for each group are shown in Table 5. The skin " $\mathrm{L}$ " values were significantly lower in hens than in cocks $(\mathrm{P}<$ 0.05). In addition, the "L" values in hens of HoFfi_ and HeFfi_groups were significantly lower compared to values obtained for the Heffi_group $(\mathrm{P}<0.05)$. The "a" values obtained for hens of HoFfi_ and HeFfi_ groups were significantly lower $(\mathrm{P}<0.05)$; "b" values were significantly higher in the latter groups, compared with the remaining four groups $(\mathrm{P}<0.05)$.

\section{Expression of skin color related genes}

The gene expression of TYRP1, TYRP2, MC1R, and EDNRB at 126 days in samples of breast skin taken from each group are shown in Figure 3. Interestingly, the mRNA levels of TYRP1 were significantly higher in HoFfli, HoFfi_, and HeFfi_groups compared with the other three groups $(\mathrm{P}<0.05)$, with the values in HoFfi_and HeFfi_groups significantly or nonsignificantly higher than in the HoFfli group (Figure $3 \mathrm{~A}$ ). TYRP2 mRNA levels in the HoFfi and HeFfi_groups were significantly higher compared with those in the other four groups $(\overline{\mathrm{P}}$ $<0.05$ ) (Figure 3B). MC1R mRNA levels in the HoFfli, HoFfi_, and HeFfli groups were sig- 
nificantly higher in comparison with those in the other three groups $(\mathrm{P}<0.05)$. Of note, $M C 1 R$ expression in HoFfli and HoFfi_groups was significantly increased compared with that in the HeFfIi group $(\mathrm{P}<0.05)$ (Figure $3 \mathrm{C})$. mRNA levels of $E D N R B$ were significantly lower in the Heffli and Heffi_groups compared with the other four groups $(\mathrm{P}<0.05)$ (Figure 3D).

Table 5. Skin "L," "a," and "b" values of test chickens at 126 days (mean $\pm \mathrm{SD}$ ).

\begin{tabular}{|c|c|c|c|c|c|}
\hline \multirow[t]{2}{*}{ Sex } & \multirow[t]{2}{*}{$\mathrm{P}$ group } & \multirow[t]{2}{*}{$\mathrm{F}_{1}$ Group } & \multicolumn{3}{|c|}{ Skin color value } \\
\hline & & & $\mathrm{L}$ & $\mathrm{a}$ & $\mathrm{B}$ \\
\hline \multirow[t]{3}{*}{$\hat{\jmath}$} & HoFF & HoFfli & $65.10 \pm 1.86^{\mathrm{c}}$ & $0.30 \pm 1.13^{b}$ & $-0.42 \pm 1.62^{\mathrm{a}}$ \\
\hline & $\mathrm{HeFf}$ & Heffli & $65.24 \pm 2.21^{\mathrm{c}}$ & $1.21 \pm 1.53^{\mathrm{b}}$ & $-1.13 \pm 1.49^{\mathrm{a}}$ \\
\hline & & HeFfli & $64.99 \pm 1.73^{c}$ & $0.51 \pm 1.14^{\mathrm{b}}$ & $-1.30 \pm 1.44^{\mathrm{a}}$ \\
\hline \multirow[t]{3}{*}{ 우 } & HoFF & HoFfi_ & $59.14 \pm 1.54^{\mathrm{a}}$ & $-0.30 \pm 0.82^{\mathrm{a}}$ & $0.94 \pm 0.66^{b}$ \\
\hline & $\mathrm{HeFf}$ & Heffi_- & $62.98 \pm 1.83^{b}$ & $0.36 \pm 0.75^{b}$ & $-0.31 \pm 1.16^{\mathrm{a}}$ \\
\hline & & HeFfi_- & $58.41 \pm 1.65^{\mathrm{a}}$ & $-0.40 \pm 0.57^{\mathrm{a}}$ & $1.10 \pm 1.05^{b}$ \\
\hline
\end{tabular}

HoFF: $F m$ genotype of the Dongxiang cocks was $F m / F m$ homozygous; HeFf: $F m$ genotype of the Dongxiang cocks was $\mathrm{Fm} / \mathrm{fm}$ heterozygous. HoFfli: cocks with $\mathrm{Fm} / \mathrm{fm}$ and Id/id genotype in offspring of Dongxiang $\mathrm{Fm} / \mathrm{Fm}$ homozygous; HoFfi_: hens with $F m / f m$ and $i d /$ _ genotype in offspring of Dongxiang $F m / F m$ homozygous; Heffli: cocks with $\mathrm{fm} / \mathrm{fm}$ and $\mathrm{Id} / \mathrm{id}$ genotype in offspring of Dongxiang $\mathrm{Fm} / \mathrm{fm}$ heterozygous; HeFfli: cocks with $\mathrm{Fm} / \mathrm{fm}$ and Id/id genotype in offspring of Dongxiang $\mathrm{Fm} / \mathrm{fm}$ heterozygous; Heffi_: hens with $\mathrm{fm} / \mathrm{fm}$ and $\mathrm{id} /$ genotype in offspring of Dongxiang $\mathrm{Fm} / \mathrm{fm}$ heterozygous; HeFfi_: hens with $\mathrm{Fm} / \mathrm{fm}$ and $\overline{i d} /$ _ genotype in offspring of Dongxiang $\mathrm{Fm} / \mathrm{fm}$ heterozygous. ${ }^{\mathrm{a}, \mathrm{b}}$ Difference in means between groups of the same column. Different superscript letters represent significant differences $(\mathrm{P}<0.05)$; same superscript letter represented non-significant differences $(\mathrm{P}>0.05)$.
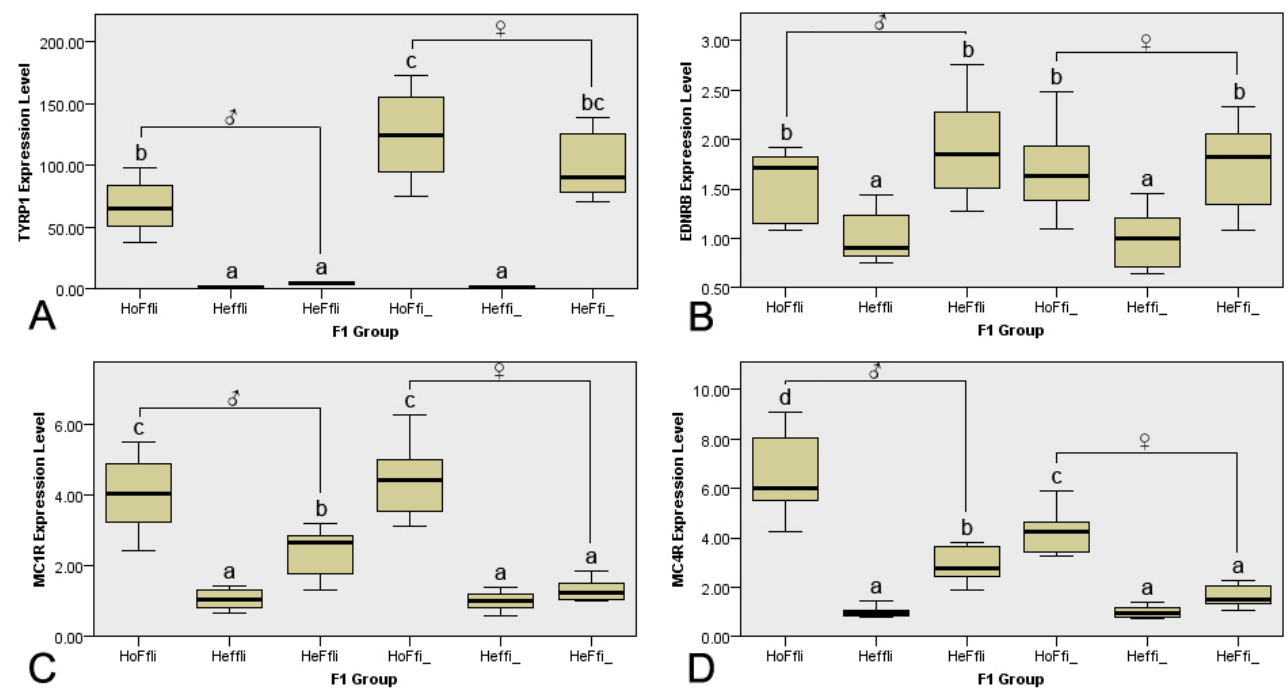

Figure 3. mRNA expression levels of TYRP1, TYRP2, MC1R, and EDNRB. X-axis represents groups of the $\mathrm{F}_{1}$ generation; Y-axis represents the mRNA expression of each gene; different letters (a, b, c, d) on box plots in each chart represent significant differences between groups (Kruskal-Wallis method, $\mathrm{P}<0.05$ ). HoFfli: cocks with $\mathrm{Fm} / \mathrm{fm}$ and Id/id genotype in offspring of Dongxiang $\mathrm{Fm} / \mathrm{Fm}$ homozygous; HoFfi_: hens with $\mathrm{Fm} / \mathrm{fm}$ and $\mathrm{id} /$ genotype in offspring of Dongxiang $\mathrm{Fm} / \mathrm{Fm}$ homozygous; Heffli: cocks with $\mathrm{fm} / \mathrm{fm}$ and $\mathrm{Id} / \mathrm{id}$ genotype in offspring of Dongxiang $\mathrm{Fm} / \mathrm{fm}$ heterozygous; HeFfli: cocks with $\mathrm{Fm} / \mathrm{fm}$ and $\mathrm{Id} / \mathrm{id}$ genotype in offspring of Dongxiang $\mathrm{Fm} / \mathrm{fm}$ heterozygous; Heffi_: hens with $\mathrm{fm} / \mathrm{fm}$ and $i d /$ _ genotype in offspring of Dongxiang Fm/fm heterozygous; HeFfi_: hens with $\mathrm{Fm} / \mathrm{fm}$ and $i d /$ /genotype in offspring of Dongxiang $\mathrm{Fm} / \mathrm{fm}$ heterozygous. 


\section{DISCUSSION}

Zhang et al.(2000) described the changes in skin color of Taihe Silky hybrids at 90 days, and Huang et al. (2003) demonstrated that there was a color change in Sichuan Mountain black chicken hybrids. Smyth (1990) suggested that the $i d$ and $W$ genes influence skin and tibia color expression in these animals by 3 -months of age. Herein, we show that the skin color of offspring generated through crossing Dongxiang with ISA became lighter with growth. At $126 \mathrm{~d}$, cocks exhibited white skin, while that of the hens was mainly light black. These findings indicate that inhibition of $I d$ gene expression in $F m$ is sex-dependent. This is because the sex chromosome of the cock harbors the $I d$ gene. Meanwhile, inhibition of $I d$ on $F m$ is time-dependent, with a gradual effect being evident with increasing age. Our data suggest that the growth stage occurring between 42 and 84 days constitutes the key period for skin color change: the probability of color change among cocks and hens peaked at this stage. Whether this phenomenon is associated with the physiological characteristics of this stage requires further study.

In addition to the $I d$ gene, genes related to plumage color such as Chromogen $(C)$, Melanin diffusion $(E)$, Barring $(B)$, Silver $(S)$, and dominant White $(I)$ all affect skin melanin deposition (Jaap, 1955; Smyth, 1994). The Dongxiang black chickens and ISA B-line layers used in this study are known for the consistency of their plumage and genetic stability. Therefore, the effect of complex plumage genetic background on skin can be effectively controlled. As a result, Dongxiang black chickens were shown to be $F m$ homozygous or heterozygous; the ratio of homozygous to heterozygous was nearly $3: 7$. The percentage of black skin in hen offspring was $100 \%$ from homozygous birds, but only $50 \%$ from heterozygous birds. Therefore, the pure-line breeding of $\mathrm{Fm} / \mathrm{Fm}$ homozygous should be favored when breeding Dongxiang black chicken. Indeed it seems that hybrids from $\mathrm{Fm} / \mathrm{Fm}$ homozygous birds showed deeper black skin which could confer greater commercial value.

Interestingly, Zhang (2010) found that MC1R and TYRP1 gene expression peaked in Silky skin at 4 weeks of age, and was relatively lower at 8 weeks and 16 weeks. In addition, Liu et al. (2010) studied Dongxiang black chicken from hatching to 112 days, and found that $M C 1 R$ expression in skin peaked at $28 \mathrm{~d}$ and decreased thereafter. Dorshorst et al. (2011) found that EDNRB2 expression was significantly different between adult black and non-black chicken, although the difference in $E D N R B$ was non-significant. We assessed gene expression in samples collected at 126 days, which was relatively late. Therefore, the results obtained for the four genes may reflect the characteristic of the test age used in this study. The difference in TYRP 1 expression was highest in skin, followed by TYRP 2 and $M C 1 R$, whereas the difference in $E D N R B$ expression was lowest. Importantly, the expression of these four genes in offspring followed the same trend as that of the $\mathrm{Fm} / \mathrm{fm}$ genotype being higher than that of the $\mathrm{fm} / \mathrm{fm}$ genotype. These findings indicate that the four genes are associated with skin color. The expression of TYRP1 and TYRP 2 showed better conformity with color test values: the expression level was significantly higher in hens than in cocks $(\mathrm{P}<0.05)$. The "L" value of hen's skin was significantly lower than that of cock's skin ( $\mathrm{P}$ $<0.05)$. These data suggest that the TYRP1 and TYRP2 genes are ideal molecular markers for skin color. The $F m / f m$ offspring of homozygous Dongxiang chickens had significantly higher expression of the TYRP1, TYRP2, and MC1R genes than did heterozygous Dongxiang chickens $(\mathrm{P}<0.05)$. This may explain the phenotypic differences between $\mathrm{Fm}$ homozygous and heterozygous birds. 


\title{
Conflicts of interest
}

The authors declare that they have no conflict of interest.

\section{ACKNOWLEDGMENTS}

\author{
Research supported by the Science and Technology Department of Zhejiang Province, \\ China (\#2012C12906-16).
}

\section{REFERENCES}

Barsh GS (1996). The genetics of pigmentation: from fancy genes to complex traits. Trends Genet. 12: 299-305.

China National Commission of Animal Genetic Resources (2011). Animal genetic resources in China: Poultry. China Agriculture Press, Beijing, 115-117.

Dorshorst B, Okimoto R and Ashwell C (2010). Genomic regions associated with dermal hyperpigmentation, polydactyly and other morphological traits in the Silkie chicken. J. Hered. 101: 339-350.

Dorshorst B, Molin AM, Rubin CJ, Johansson AM, et al. (2011). A complex genomic rearrangement involving the endothelin 3 locus causes dermal hyperpigmentation in the chicken. PLoS Genet. 7: e1002412.

Fang D, Kute T, and Setaluri V (2001). Regulation of tyrosinase-related protein-2 (TYRP2) in human melanocytes: relationship to growth and morphology. Pigment Cell Res. 14: 132-139.

Grichnik JM, Burch JA, Burchette J and Shea CR (1998). The SCF/KIT pathway plays a critical role in the control of normal human melanocyte homeostasis. J. Invest. Dermatol. 111: 233-238.

Hou L and Pavan WJ (2008). Transcriptional and signaling regulation in neural crest stem cell-derived melanocyte development: do all roads lead to Mitf? Cell Res. 18: 1163-1176.

Huang YQ, Yang ZQ, Chen W and Kang XT (2003). Observation on the inheritance of skin color, shank color in Sichuan Mountain dark-bone chickens (SMDC). J. Sich. Agricul. Univ. 21: 1-4.

Hutt PB (1949). Genetics of the Fowl. McGraw-Hill Book Co., Inc, New York.

Imokawa G, Kobayasi T and Miyagishi M (2000). Intracellular signaling mechanisms leading to synergistic effects of endothelin- 1 and stem cell factor on proliferation of cultured human melanocytes. Cross-talk via trans-activation of the tyrosine kinase c-kit receptor. J. Biol. Chem. 275: 33321-33328.

Jaap RG (1955). Shank color and barred plumage in columbian-colored chickens. Poul. Sci. 34: 389-395.

Jin EJ, Erickson CA, Takada S and Burrus LW (2001). Wnt and BMP signaling govern lineage segregation of melanocytes in the avian embryo. Dev. Biol. 233: 22-37.

Liu WB, Chen SR, Zheng JX, Qu LJ, et al. (2010). Developmental phenotypic-genotypic associations of tyrosinase and melanocortin 1 receptor genes with changing profiles in chicken plumage pigmentation. Poul. Sci. 89: 1110-1114.

Pak BJ, Li Q, Kerbel RS and Ben-David Y (2000). TYRP2-mediated resistance to cis-diamminedichloroplatinum (II) in human melanoma cells is independent of tyrosinase and TYRP1 expression and melanin content, Melanoma Res. 10: 499-505.

Sarangarajan R, Zhao Y, Babcock G, Cornelius J, et al. (2000). Mutant alleles at the brown locus encoding tyrosinaserelated protein-1 (TRP-1) affect proliferation of mouse melanocytes in culture. Pigment Cell Res. 13: 337-344.

Shu W, Yang SL, Deng WD and Mao HM (2006). MC1R gene polymorphism of black bone sheep. China Anim. Husbandry Vet. Med. 4: 001.

Smyth JR (1990). Genetics of plumage, skin and eye pigmentation in chickens. In Poultry Breeding and Genetics (Crawford RD, ed.), Elsevier, Amsterdam 109-167.

Smyth JR (1994). MelaninPigmentation: Its Biological Roles, Inheritance and Expressionin the Chicken. Pout. Sci. 73: 106-117.

Stolle I (1968). Vergleichende Untersuchungen über die Pigmentierung des Seidenhuhns, des Italienerhuhns und ihrer Bastarde. Wilhelm Roux'Archiv für Entwicklungsmechanik der Organismen, 161: 30-48.

Wu GM (2003). Studying on Genes Related with Melanin in Black Chicken. Doctoral thesis, Hunan Agricultural University. Available at [http://cnki.gzlib.gov.cn/kcms/detail/detail.aspx?recid=\&FileName=2004089236.nh\&DbN ame $=$ CDFD9908\&DbCode $=$ CDFD\&uid $=$ WDVNUU1hL1pZa2RlelE9PQ $==]$.

Zhang LH (2010). Effects of Dietary Tyrosine and Phenylalanine Levels on Performance and Expression of Melanin Related Gene of Silky Fowls. Master's thesis, Henan Agricultural University. Available at [http://cnki.gzlib.gov.cn/

Genetics and Molecular Research 14 (3): 11551-11561 (2015)

CFUNPEC-RP www.funpecrp.com.br 
$\mathrm{kcms} /$ detail/detailall.aspx $?$ filename $=2010270702 . \mathrm{nh} \& \mathrm{db}$ code $=$ CMFD $\&$ dbname $=$ CMFD2011]

Zhang XY, Huang FM, Zhao DW and Bu Z (2000). Observation on sex-linkage inheritance of skin color in some local breeds of chicken. Yi Chuan Xue Bao. 27: 866-869. 